\title{
Neuroendoscopic approach to intraventricular lesions
}

\author{
Michael R. Gaab, M.D., Ph.D., and Henry W. S. Schroeder, M.D. \\ Department of Neurosurgery, Ernst Moritz Arndt University, Greifswald, Germany
}

Object. The purpose of this study was to determine the efficacy of endoscopic treatment in patients with intraventricular tumors.

Methods. A series of 30 patients with endoscopically treated intraventricular lesions is reported. The lesions included seven colloid cysts, six astrocytomas, three subependymomas, two ependymomas, and one each of the following: pineoblastoma, pineocytoma/pineoblastoma (intermediate type), epidermoid cyst, pineal cyst, medulloblastoma, arteriovenous hemangioma, cavernoma, choroid plexus papilloma, pituitary adenoma, craniopharyngioma, melanoma, and germinoma. Total tumor resections, partial resections, biopsies, stent implantations, septostomies, and third ventriculostomies were performed. In two cases (two subependymomas $>2 \mathrm{~cm}$ in diameter), piecemeal endoscopic resection was ineffective because of the very firm consistency of the tumors. Therefore the endoscopic procedure was discontinued and the tumors were removed microsurgically. In the remaining cases the procedures were completed as planned. Even in the presence of difficulties such as poor orientation or significant bleeding, there was no need to abandon the endoscopic procedure. A total of 28 strictly endoscopic interventions were performed, in which the average duration was 85 minutes (range 35-170 minutes). All colloid cysts and the epidermoid lesion were completely evacuated and the capsules were widely resected. Total extirpation of solid tumors was achieved in five cases, whereas most astrocytomas were partially resected. The hydrocephalus-related symptoms resolved in all of the 22 patients with cerebrospinal fluid pathway obstruction. There were no endoscopy-related deaths. In two cases, major bleeding occurred and was controlled endoscopically. The authors observed one case of meningitis, one of mutism, two of memory loss attributed to forniceal injury, one of transient trochlear palsy after a biopsy specimen of an aqueductal tumor was obtained, and one of transient confusion after a biopsy specimen of a germinoma was obtained.

Conclusions. In the authors' preliminary experience, the endoscopic approach was found to be safe and effective. In this series, it was possible to achieve relief of noncommunicating hydrocephalus, tumor resections, and even complete tumor removals by using endoscopic techniques. Based on the results, the authors believe that endoscopic techniques should be considered in the treatment of selected intraventricular lesions.

Key Words * intraventricular tumor * neuroendoscopy * third ventriculostomy * colloid cyst * stent * endoscopic tumor resection

Tumors that arise within the ventricular system of the brain represent a major neurosurgical challenge. These lesions located deep inside the brain must be approached from a considerable distance through normal brain tissue. Dissection and brain retraction should be minimized to avoid damage to important brain structures such as the thalamus, caudate nucleus, fornix, and others. In general, intraventricular lesions are managed by using microsurgical approaches.[16] The development of and improvements in operative instruments, microscopes, and microsurgical techniques has reduced considerably the surgical mortality and morbidity rates. However, in selected cases a neuroendoscopic approach to intraventricular lesions might prove to be as effective as microsurgery and less invasive. During endoscopic procedures brain retraction can be largely avoided and the lesions can be well visualized with the aid of the superb Hopkins rod-lens scopes.[57] The origin of the blood supply and the amount of vasculature of the tumor capsule can be defined before obtaining a biopsy specimen of the tumor or beginning resection. In addition to lesion removal it is often possible to restore obstructed cerebrospinal fluid (CSF) pathways via the same approach. This is accomplished by means of ventriculostomies, septostomies, and stent implantations.[49] We report on a series of 30 patients harboring intraventricular lesions who underwent endoscopic treatment within a time period of 3 years and 8 months. 
Thirty patients with intraventricular lesions underwent endoscopic treatment at our institution between February 1993 and October 1996. All patients were prospectively examined.

\section{Age, Sex, Presentation, and Diagnostic Tests}

The clinical characteristics of the patients are given in Table 1. The series consisted of 19 males and 11 females. Eight patients were younger than 14 years of age at the time of surgery. Twenty-two patients suffered from symptoms of increased intracranial pressure (ICP), three had seizures, and four experienced gait disturbances. Four patients suffered from diplopia and two from hemianopsia. Diabetes insipidus, memory problems, pituitary insufficiency, balance problems, paresthesia, and intraventricular bleeding were present in one patient each. Two patients suffered from headaches unrelated to intracranial hypertension. Two tumors were asymptomatic and were found incidentally. All patients underwent contrast-enhanced computerized tomography (CT) and/or magnetic resonance (MR) imaging.

TABLE 1

SUMMARY OF CL NICAL CHARACTER ISTKS IN 30 PATIENTS UNDERGONG ENDOSCOPK PROCEDURES FOR INTRAVENTR CULAR LESIONS*

\begin{tabular}{|c|c|c|c|c|c|c|c|c|c|}
\hline $\begin{array}{l}\text { Case } \\
\text { No. }\end{array}$ & $\begin{array}{l}\text { Age } \\
(y+s), \\
\text { Sex }\end{array}$ & $\begin{array}{l}\text { Clirical } \\
\text { Findngs } \\
\end{array}$ & $\begin{array}{l}\text { Tumor } \\
\text { Location }\end{array}$ & $\begin{array}{l}\text { Hydro- } \\
\text { ceph- } \\
\text { alus } \\
\end{array}$ & $\begin{array}{l}\text { Endoscopic } \\
\text { Procedure }\end{array}$ & $\begin{array}{l}\text { Additional } \\
\text { Treatment }\end{array}$ & $\begin{array}{l}\text { Histological } \\
\text { Findngs }\end{array}$ & $\begin{array}{c}\text { Follow } \\
U_{p} \\
(m \infty)\end{array}$ & $\begin{array}{l}\text { Outcome, Postop } \\
\text { CTIMR Image }\end{array}$ \\
\hline 1 & $51, M$ & $\begin{array}{l}\text { headache, } \\
\text { paresthesia. }\end{array}$ & frontel horn & + & $\begin{array}{l}\text { endosco py aban- } \\
\text { doned; microsur- } \\
\text { gical removal }\end{array}$ & - & $\begin{array}{l}\text { subependy- } \\
\text { moma }\end{array}$ & 46 & $\begin{array}{l}\text { no complaints, no recurrence, } \\
\text { smaller uentides }\end{array}$ \\
\hline 2 & $60, M$ & $\begin{array}{l}\text { headache, } \\
\text { womiting, } \\
\text { drowsiness }\end{array}$ & 3rd ventricle & + & cyst removal & - & colloid cyst & 45 & $\begin{array}{l}\text { no complaints, no recurrence, } \\
\text { smaller tentides }\end{array}$ \\
\hline 3 & 13 , M & headache & $\begin{array}{l}\text { lat \& } 3 \text { rd } \\
\text { ventride, } \\
\text { thalamus }\end{array}$ & + & septostomy & $\begin{array}{l}\text { microsurgical } \\
\text { resection, } \\
\text { shunt, che- } \\
\text { motherapy, } \\
\text { radiation }\end{array}$ & $\begin{array}{l}\text { high-grade } \\
\text { astrocytoma }\end{array}$ & 8 & $\begin{array}{l}\text { headache im proved, smaller } \\
\text { wentrides, died after } 8 \text { mos } \\
\text { due to tum or progression }\end{array}$ \\
\hline 4 & $12, M$ & $\begin{array}{l}\text { headache, } \\
\text { nausea, } \\
\text { womiting, } \\
\text { diplopia. }\end{array}$ & $\begin{array}{l}\text { 3rd wentricle, } \\
\text { pineal re- } \\
\text { gion }\end{array}$ & + & $\begin{array}{l}\text { 3rd wentriculo- } \\
\text { stomy }\end{array}$ & $\begin{array}{l}\text { microsurgical } \\
\text { removal, che- } \\
\text { motherapy, } \\
\text { radiation }\end{array}$ & $\begin{array}{l}\text { high-grade } \\
\text { epend y } \\
\text { moma. }\end{array}$ & 42 & $\begin{array}{l}\text { no complaints, no recurrence, } \\
\text { smaller ventides }\end{array}$ \\
\hline 5 & $4, M$ & $\begin{array}{l}\text { gait disturb- } \\
\text { ance (in- } \\
\text {-didental } \\
\text { discovery) }\end{array}$ & trigone & - & tumor remo wal & - & $\begin{array}{l}\text { choroid plex- } \\
\text { us papilloma }\end{array}$ & 42 & $\begin{array}{l}\text { gait unchanged, no redur- } \\
\text { renoe }\end{array}$ \\
\hline $6 \dagger$ & $7, M$ & $\begin{array}{l}\text { headache, } \\
\text { diplopia, } \\
\text { balance } \\
\text { protlems }\end{array}$ & $\begin{array}{l}\text { 1) 3rd wen- } \\
\text { tricle } \\
\text { 2) } 4 \text { th ien- } \\
\text { tricle }\end{array}$ & + & $\begin{array}{l}\text { 3rd wentriculo- } \\
\text { stomy, remo- } \\
\text { val of } 3 \text { rd wen- } \\
\text { tricle metastasis }\end{array}$ & $\begin{array}{l}\text { microsurgical } \\
\text { removal, che- } \\
\text { motherapy, } \\
\text { radiation }\end{array}$ & $\begin{array}{l}\text { medullo- } \\
\text { tlastoma }\end{array}$ & 41 & $\begin{array}{l}\text { no complaints, smaller wen- } \\
\text { tricles, spinal me tastases } \\
\text { after } 38 \text { mos }\end{array}$ \\
\hline 7 & $30, M$ & $\begin{array}{l}\text { headache, } \\
\text { nausea }\end{array}$ & 3rd ventricle & + & cyst removal & - & colloid cyst & 40 & $\begin{array}{l}\text { no complaints, no recurrence, } \\
\text { smaller ventides }\end{array}$ \\
\hline 8 & $46, M$ & $\begin{array}{l}\text { headache, } \\
\text { seizure }\end{array}$ & $\begin{array}{l}\text { 3rd wentricle, } \\
\text { pineal re- } \\
\text { gion }\end{array}$ & + & $\begin{array}{l}\text { 3rd wentriculo- } \\
\text { stomy, tumor } \\
\text { tiopsy }\end{array}$ & $\begin{array}{l}\text { microsurgical } \\
\text { removal, } \\
\text { radiation }\end{array}$ & pineotlastoma & 34 & $\begin{array}{l}\text { no complaints, smaller wentri- } \\
\text { cles, tumor regression, } \\
\text { diplopia after microsurgery }\end{array}$ \\
\hline 9 & $28, M$ & headache & $\begin{array}{l}\text { body of lat } \\
\text { wentride }\end{array}$ & - & tumor resection & radiation & $\begin{array}{l}\text { high-grade } \\
\text { epend ymoma. }\end{array}$ & 33 & headache, tumor regression \\
\hline 10 & $28, F$ & $\begin{array}{l}\text { headache, } \\
\text { nausea, } \\
\text { womiting }\end{array}$ & 3rd ventricle & + & cyst removal & - & colloid cyst & 29 & $\begin{array}{l}\text { no complaints, no recurrence, } \\
\text { smaller uentides }\end{array}$ \\
\hline 11 & $58, M$ & seizure & frontel horn & - & tumor remo val & - & $\begin{array}{l}\text { subependy- } \\
\text { moma }\end{array}$ & 27 & no complaints, no recurrence \\
\hline
\end{tabular}




\begin{tabular}{|c|c|c|c|c|c|c|c|c|c|}
\hline $\begin{array}{l}\text { Case } \\
\text { No. }\end{array}$ & $\begin{array}{l}\text { Age } \\
\stackrel{[y s]}{S e x}\end{array}$ & $\begin{array}{l}\text { Clirical } \\
\text { Findings }\end{array}$ & $\begin{array}{l}\text { Tumor } \\
\text { Location }\end{array}$ & $\begin{array}{l}\text { Hydro- } \\
\text { ceph- } \\
\text { alus }\end{array}$ & $\begin{array}{l}\text { Endoscopic } \\
\text { Procedure }\end{array}$ & $\begin{array}{l}\text { Additional } \\
\text { Treatmert }\end{array}$ & $\begin{array}{l}\text { Histological } \\
\text { Findngs }\end{array}$ & $\begin{array}{l}\text { Follow } \\
U_{p} \\
(m \infty s)\end{array}$ & $\begin{array}{l}\text { Outcome, Postop } \\
\text { CTIMR Image }\end{array}$ \\
\hline 12 & $12, F$ & $\begin{array}{l}\text { headache, } \\
\text { hemian- } \\
\text { opsia }\end{array}$ & $\begin{array}{l}\text { 3rd wentricle, } \\
\text { in tra-, su-, } \\
\text { pra-, \& pa- } \\
\text { rasellar }\end{array}$ & 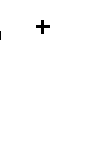 & $\begin{array}{l}\text { tumor cyst re- } \\
\text { section, stent, } \\
\text { septostomy }\end{array}$ & $\begin{array}{l}\text { microsurgical } \\
\text { removal }\end{array}$ & $\begin{array}{l}\text { pituitary ad- } \\
\text { enoma }\end{array}$ & 6 & $\begin{array}{l}\text { no complaints, smaller wentri- } \\
\text { cles, died after microsur- } \\
\text { gery }\end{array}$ \\
\hline 13 & $61, F$ & $\begin{array}{l}\text { headache, } \\
\text { womiting, } \\
\text { drowsiness }\end{array}$ & 3rd wentricle & + & cyst removal & - & colloid cyst & 26 & $\begin{array}{l}\text { no complaints, no recurrence, } \\
\text { smaller uentides }\end{array}$ \\
\hline 14 & 16 , M & $\begin{array}{l}\text { headache, } \\
\text { nausea, } \\
\text { womiting }\end{array}$ & 3rd wentricle & + & $\begin{array}{l}\text { 3rd ventriculo } \\
\text { stomy, tumor } \\
\text { biopsy }\end{array}$ & radiation & $\begin{array}{l}\text { high-grade } \\
\text { astrocytoma }\end{array}$ & 21 & $\begin{array}{l}\text { no complaints, no tum or pro- } \\
\text { gression, smaller uentrides }\end{array}$ \\
\hline 15 & $44, F$ & $\begin{array}{l}\text { headache, } \\
\text { nausea, } \\
\text { womiting }\end{array}$ & trigone & - & tumor remo wal & - & cavernoma & 19 & $\begin{array}{l}\text { permanent memory loss, no } \\
\text { redurrence }\end{array}$ \\
\hline 16 & $61, F$ & $\begin{array}{l}\text { incidental } \\
\text { discovery }\end{array}$ & trigone & - & tumor remo wal & - & hemangioma & 19 & no complaints, no recurrence \\
\hline 17 & 36 , M & $\begin{array}{l}\text { headache, } \\
\text { nausea. }\end{array}$ & 3rd wentricle & + & cyst removal & $\begin{array}{l}\text { extemal wen- } \\
\text { tricular drain- } \\
\text { age for } 24 \mathrm{hrs}\end{array}$ & colloid cyst & 18 & $\begin{array}{l}\text { no complaints, no redurence, } \\
\text { smaller wentides }\end{array}$ \\
\hline 18 & $62, M$ & $\begin{array}{l}\text { drowsiness, } \\
\text { confusion }\end{array}$ & $\begin{array}{l}\text { 3rd wentricle, } \\
\text { midtrain }\end{array}$ & + & $\begin{array}{l}\text { 3rd wentriculo- } \\
\text { stomy, tumor } \\
\text { tiopsy }\end{array}$ & - & $\begin{array}{l}\text { melanoma } \\
\text { metastasis }\end{array}$ & $\begin{array}{l}5 \\
\text { days }\end{array}$ & died of tumor progression \\
\hline 19 & $61, F$ & $\begin{array}{l}\text { headache, } \\
\text { confusion, } \\
\text { gait disturb- } \\
\text { ances }\end{array}$ & 3rd wentricle & + & $\begin{array}{l}\text { tumor remo vel, } \\
\text { stent, septo- } \\
\text { stom y }\end{array}$ & - & $\begin{array}{l}\text { epidermoid } \\
\text { cyst }\end{array}$ & 15 & $\begin{array}{l}\text { gait im pro ied, no he adache, } \\
\text { no confusion, epidermoid } \\
\text { recurred, smaller wentricles }\end{array}$ \\
\hline 20 & $38, F$ & $\begin{array}{l}\text { headache, } \\
\text { seizure }\end{array}$ & frontal horn & - & $\begin{array}{l}\text { endosco py aban- } \\
\text { doned, micro- } \\
\text { surgical removal }\end{array}$ & - & $\begin{array}{l}\text { subependy- } \\
\text { moma. }\end{array}$ & 14 & $\begin{array}{l}\text { transient memory loss \& } \\
\text { mutism, no recurrence }\end{array}$ \\
\hline 21 & $46, F$ & $\begin{array}{l}\text { headache, } \\
\text { womiting, } \\
\text { loss of con- } \\
\text { sciousness, } \\
\text { dizziness }\end{array}$ & $\begin{array}{l}\text { foramen of } \\
\text { Monro }\end{array}$ & + & $\begin{array}{l}\text { tumor resection, } \\
\text { stent, septo- } \\
\text { stomy }\end{array}$ & - & $\begin{array}{l}\text { lo whgrade as } \\
\text { trocytoma. }\end{array}$ & 12 & $\begin{array}{l}\text { no complaints, residual tumor, } \\
\text { no tumor progression, } \\
\text { smaller ientrides }\end{array}$ \\
\hline
\end{tabular}


TABLE 1, continued

SUMMARY OF CL NICAL CHARACTERISTKS IN 30 PATIENTS UNDERGONG ENDOSCOPK PROCEDURES FOR INTRAVENTRICULAR LESIONS*

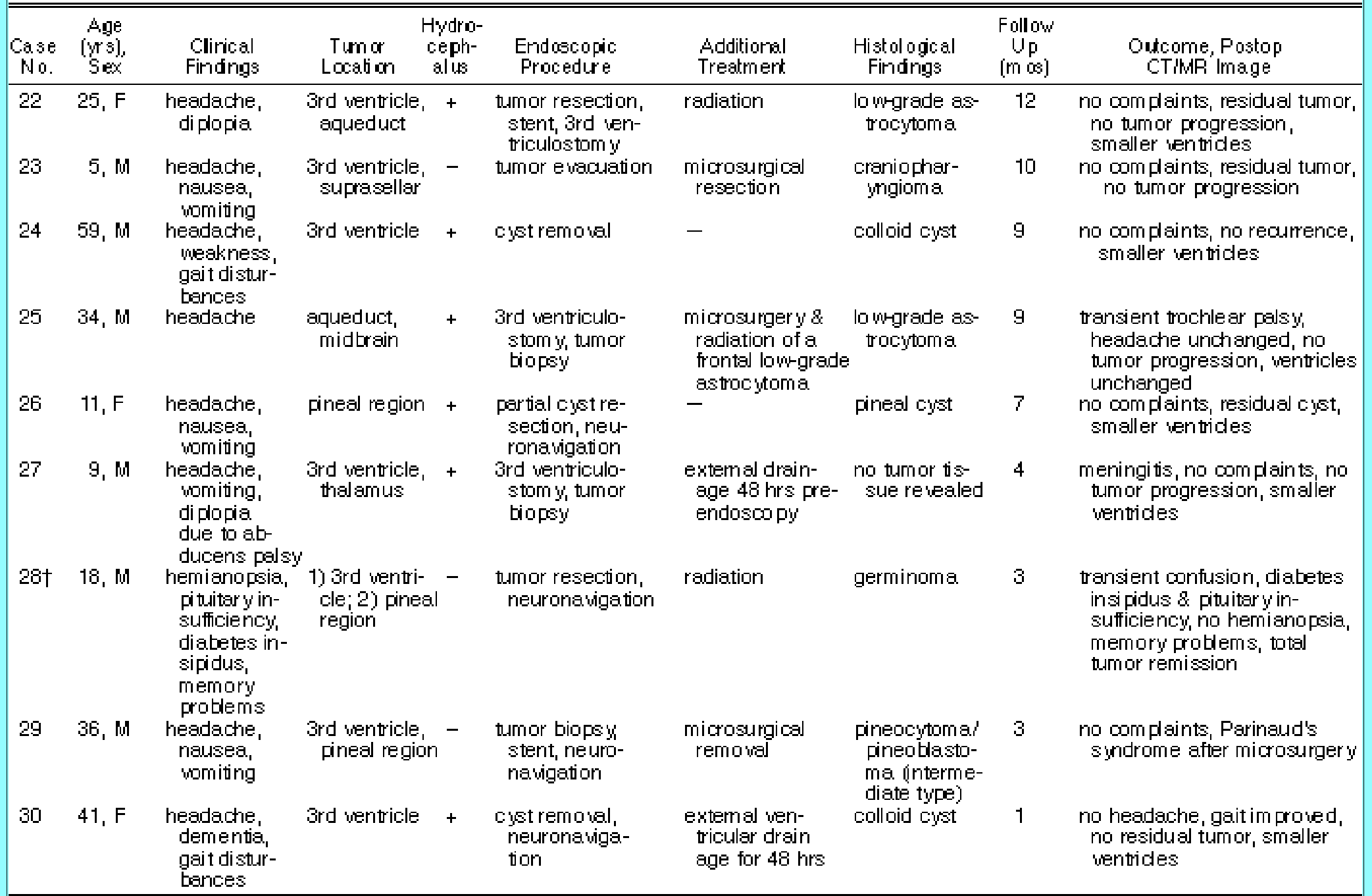

$*=$ present; - absent; - = none.

$\dagger$ Two separate lesions, both locations specified.

\section{Endoscopic Treatment}

Details regarding the endoscopic procedures and additional treatment are given in Table 1. In general, patients were placed supine with their heads tilted slightly forward. The operating field was prepared and draped to allow immediate open microsurgical intervention in case of ineffective tumor removal or complications. The operating microscope and microsurgical instruments were always ready for use. All procedures were performed after the patients underwent induction of general anesthesia. Just before surgery the patients received a bolus dose of $40 \mathrm{mg}$ of dexamethasone, and $4 \mathrm{mg}$ of dexamethasone were administered every 6 hours for 2 days thereafter. Antibiotic drugs were not administered routinely. For removal of intraventricular tumors we used the rigid scopes of our Gaab universal neuroendoscopy system (Karl Storz GmbH and Co., Tuttlingen, Germany; and Codman and Shurtleff, Inc., Randolph, MA).[26] Flexible scopes were attached for the final inspection.

In most operations, a burr hole was made based on information obtained from CT or MR images,[27] although in four patients (Cases 26 and 28-30), we used infrared-based computerized neuronavigation (Surgical Microscope Navigator; Carl Zeiss, Oberkochen, Germany). In the majority of patients, a transcortical approach was used, but in two patients (Cases 15 and 16), we used a transcallosal approach. After the dura had been incised, the operating sheath containing the trocar was inserted freehand or with the aid of navigational guidance into the ventricle and fixed with two retractor arms. The trocar was removed and the rigid rod-lens diagnostic scope was introduced. The tumors were inspected and feeding arteries were visualized. After exploration of the lesions, the diagnostic scope was replaced by the operating scope. At the beginning of tumor dissection vessels feeding the capsule were coagulated by means of the bipolar diathermy probe or neodymium:yttrium-aluminum-garnet (Nd:YAG) laser (Opmilas YAG-M, $1.064 \mu \mathrm{m}$; Carl Zeiss) in noncontact mode. Specimens were taken for immediate histological examination. Tumor removal usually started with intracapsular debulking, followed by dissection in the plane between the tumor and brain tissue, in some cases by cutting with the Nd:YAG laser in contact mode. During this dissection, feeding arteries were 
identified early and cauterized before bleeding obscured a clear view. After separating the lesion from the brain, a piecemeal removal of tumor tissue was performed with the aid of grasping and biopsy forceps. Colloid cysts were opened with grasping forceps and the contents were aspirated. The contents were partially solid in all cysts, and as far as possible the solid parts and the capsule were removed with forceps. After completion of the procedure, the region of resection was carefully inspected with the diagnostic scope and sometimes also with flexible scopes to assure sufficient hemostasis. In cases in which the CSF pathways could not be restored by tumor removal, a third ventriculostomy or septostomy was performed with the aid of a No. 3 French Fogarty balloon catheter. Stents were implanted into the aqueduct and the foramen of Monro to maintain CSF circulation in case of tumor recurrence or growth. The ventricles were vigorously irrigated to remove any clots, and the operating sheath was withdrawn with the endoscope inside to look for active bleeding in the puncture channel. To avoid aseptic meningitis, no external ventricular drains were inserted, except in the epidermoid (Case 19) and one of the colloid cysts (Case 17). We packed the burr hole with gelatin sponge and tightly sutured the galea to prevent subgaleal CSF accumulation and fistulas. The skin was closed by means of a running atraumatic suture.

All procedures were performed in concert with continuous irrigation with lactated Ringer's solution at $37^{\circ} \mathrm{C}$ to maintain a clear view.[58] To prevent dangerous increases in ICP, care was taken to maintain a sufficient outflow of irrigating fluid. Minor bleeding usually ceased after a few minutes of irrigation. Larger vessels that had been in danger were coagulated with the bipolar coagulation probe. The Nd:YAG laser was used to remove three tumors (Cases 5, 11, and 17). In two patients (Cases 16 and 24), it was necessary to aspirate the CSF and to continue surgery in a dry field. With this dry field technique, bleeding vessels were more easily visible and hemostasis was quickly achieved because blood no longer contaminated the CSF and obscured the surgeon's view.

\section{RESULTS}

Patient outcomes, follow-up periods, histological findings, and CT and MR image changes are presented in Table 1. The follow-up period ranged from 1 to 46 months (one patient died 5 days after undergoing operation). The histological investigation revealed seven colloid cysts, five astrocytomas, three subependymomas, two ependymomas, and one each of the following: pineoblastoma, pineocytoma/pineoblastoma (intermediate type), epidermoid cyst, pineal cyst, medulloblastoma, craniopharyngioma, arteriovenous hemangioma, cavernoma, choroid plexus papilloma, pituitary adenoma, melanoma, and germinoma. In one specimen, no abnormal tissue was identified, but the lesion was presumed to be a low-grade astrocytoma.

The pineal cyst was opened and partially resected to obtain a wide communication to the third ventricle, and the symptoms resolved immediately. A marked cyst reduction and normal ventricles were demonstrated on the postoperative MR image. All colloid cysts and the epidermoid cyst were completely evacuated and the capsules widely resected. In five of the colloid cysts, a total removal was feasible, which means that no residual capsule was visible endoscopically or on the postoperative MR images (Fig. 1). Nevertheless, this does not mean "total resection" in a histological sense. A contrast-enhanced MR image did not rule out the possibility that vital capsule tissue may have remained in the third ventricle. In the other two colloid cysts (Cases 2 and 7), small remnants of the capsule that were attached to the roof of the third ventricle were left in place to avoid uncontrolled bleeding from the internal cerebral veins. No colloid cyst recurrence has yet been identified on the postoperative MR images. The epidermoid cyst recurred after 12 months. However, the ventricles remained small, indicating patency of the septostomy and the stent inserted from the lateral ventricle through the foramen of Monro and aqueduct into the fourth ventricle. The patient is doing well, with no complaints. 


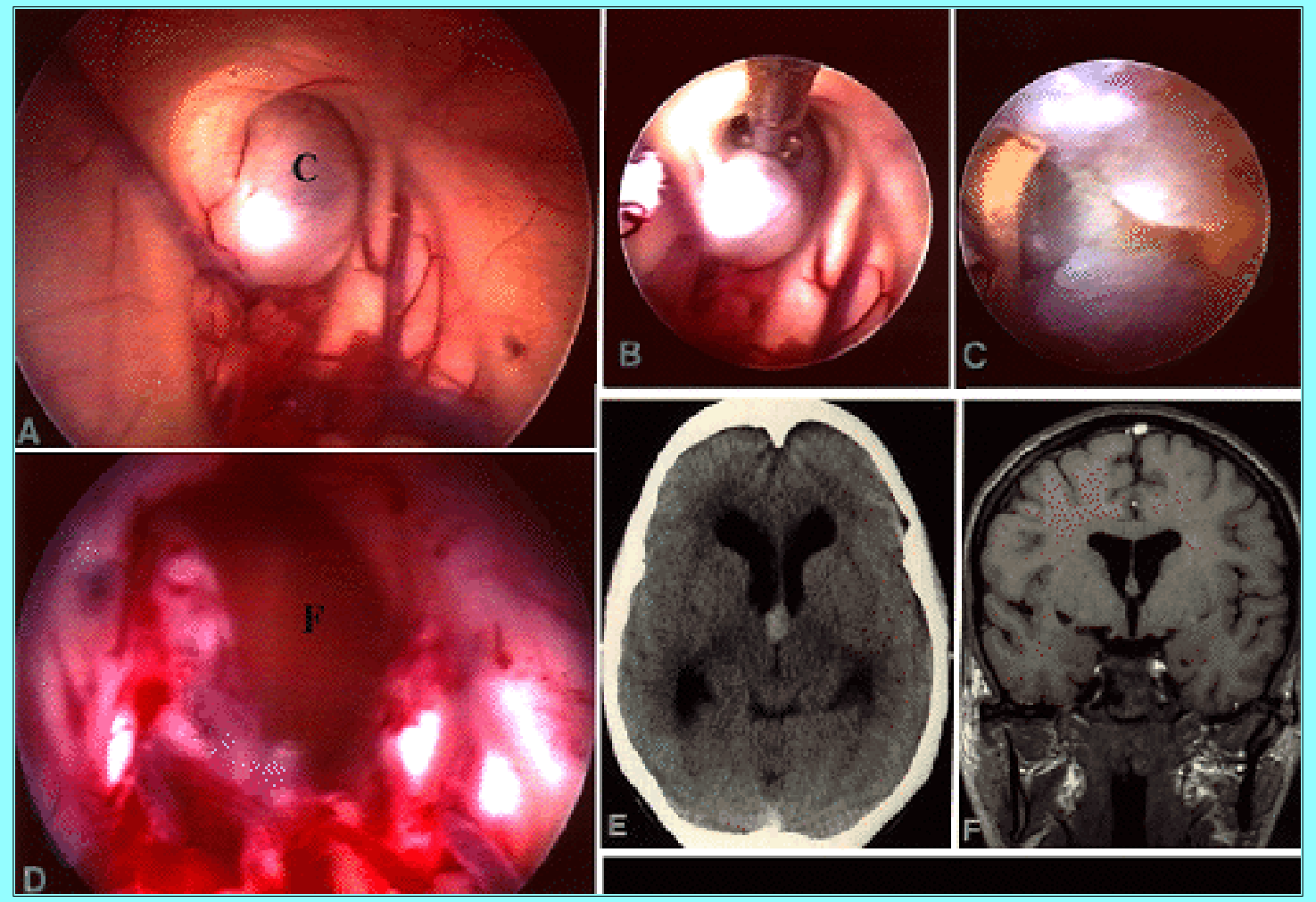

Fig. 1. Case 10. A-D: Intraoperative photographs showing neuroendoscopic views. A: Colloid cyst (C) obstructing the foramen of Monro. B: Opening of the cyst by means of biopsy forceps. C: Solid contents are seen bulging out of the cyst. D: Foramen of Monro (F) after complete cyst removal. E: Axial noncontrast-enhanced CT scan displaying a hyperdense space-occupying lesion within the third ventricle with accompanying obstructive hydrocephalus. F: Coronal contrast-enhanced $\mathrm{T}_{1}$-weighted MR image obtained 12 months postsurgery demonstrating reduction of ventricular size and no cyst recurrence.

A total endoscopic extirpation of solid tumors was achieved in the cavernoma (Fig. 2), choroid plexus papilloma, medulloblastoma metastasis, arteriovenous angioma, and one of the subependymomas. No recurrences have been detected yet on follow-up MR images. 


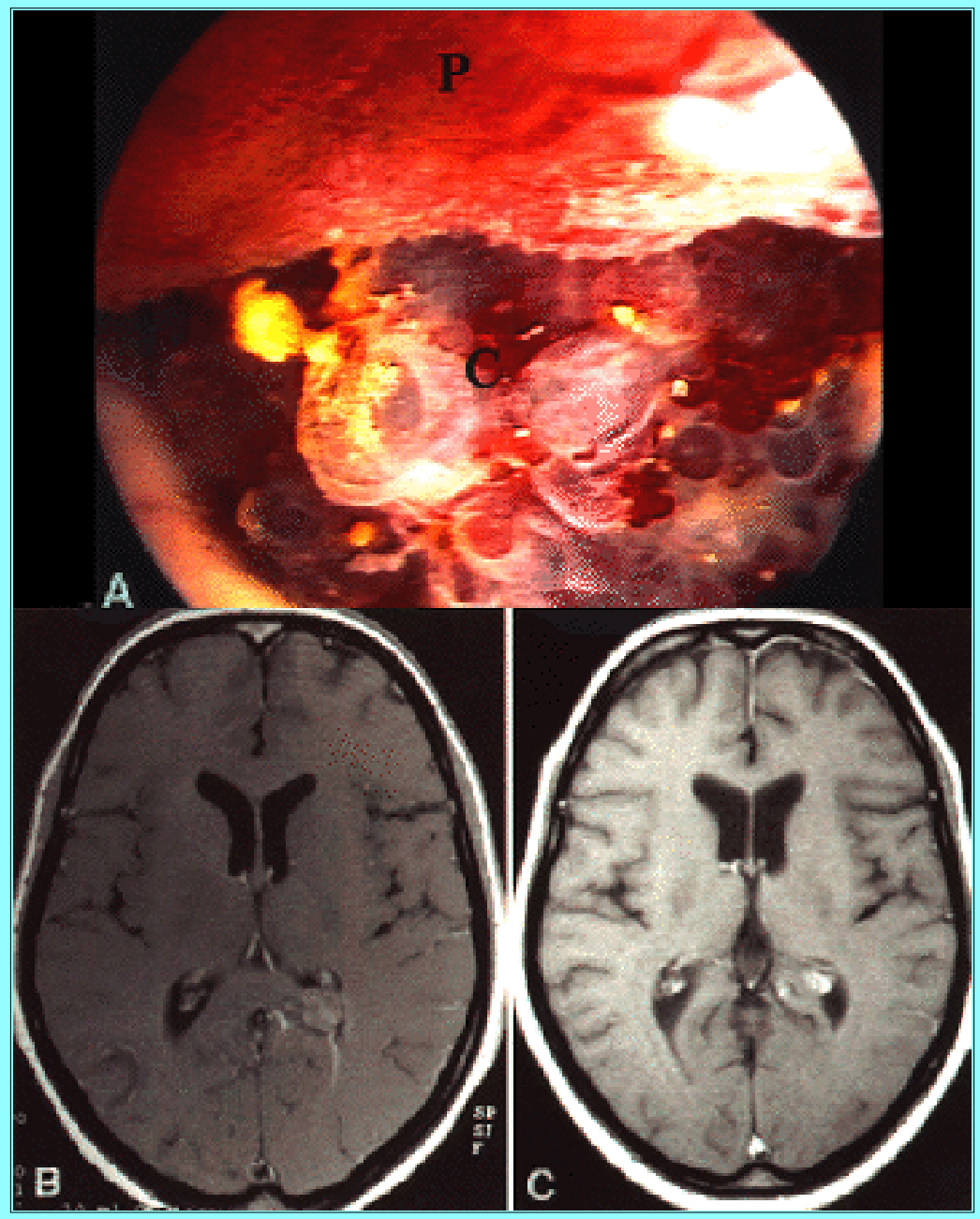

Fig. 2. Case 15. A: Intraoperative photograph showing endoscopic view of cavernoma (C) adjacent to choroid plexus (P). B: Axial contrast-enhanced $\mathrm{T}_{1}$-weighted MR image showing an enhancing lesion within the trigone. $\mathrm{C}$ : Axial contrast-enhanced $\mathrm{T}_{1}$-weighted $\mathrm{MR}$ image obtained 12 months postsurgery showing complete cavernoma removal.

Most astrocytomas were partially resected; one nearly completely. A third ventriculostomy was performed in eight patients (Cases 4, 6, 8, 14, 18, 22, 25, and 27) and a septostomy in four (Cases 3, 12, 19, and 21). A stent was implanted into the aqueduct (Fig. 3) in three patients (Cases 12, 22, and 29) and in the foramen of Monro in one (Case 21). In the patient in Case 19, the stent was inserted from the lateral ventricle through the foramen of Monro and aqueduct into the fourth ventricle. In six patients (Cases 8, 14, 18, 25, 27, and 29), a biopsy was performed. In the patient in Case 27, no tumor tissue was identified in the biopsy specimen. However, because its appearance on MR imaging was typical for a low-grade astrocytoma, no additional diagnostic measures were undertaken. This patient has been regularly followed with repeated MR imaging. 


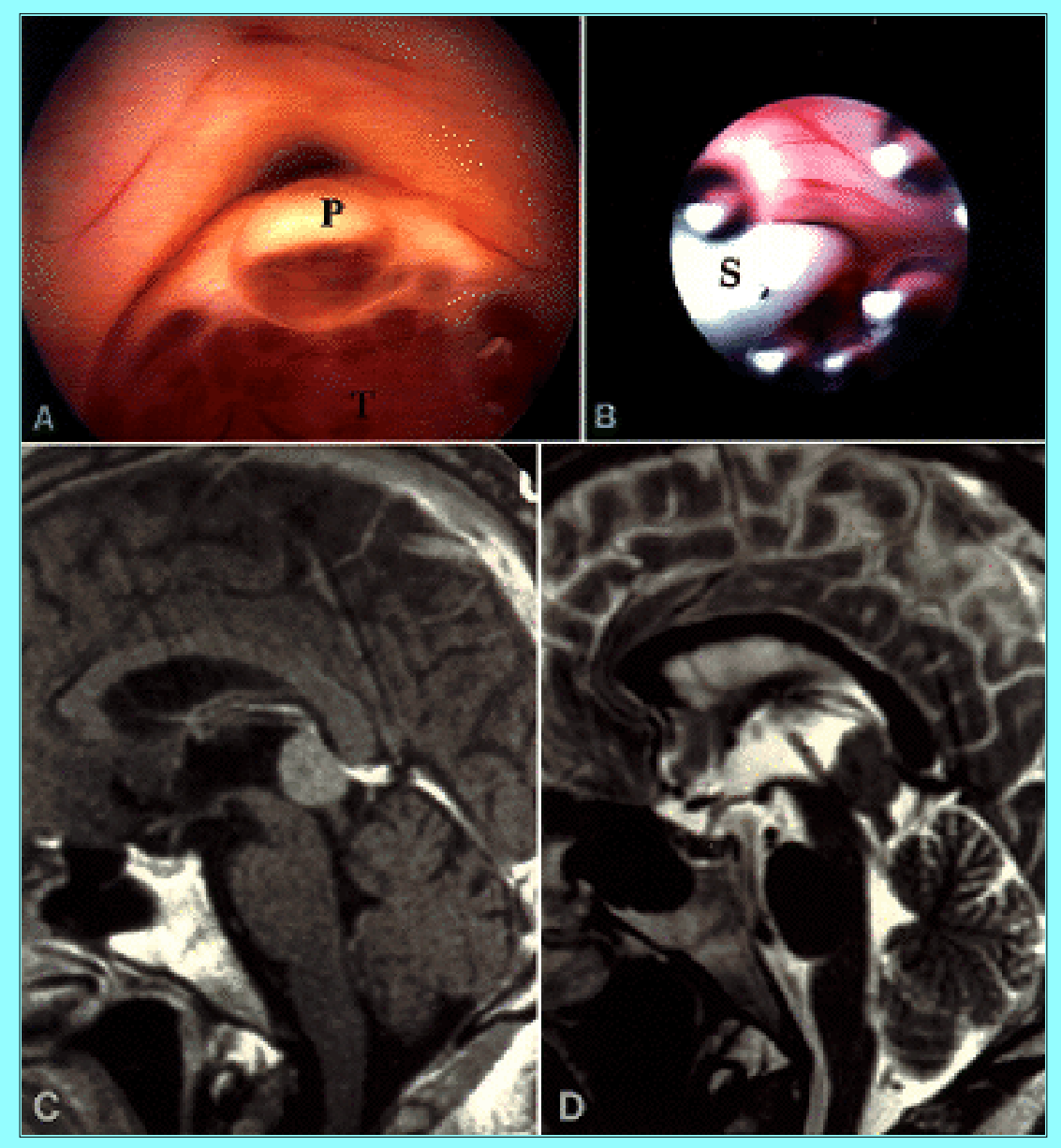

Fig. 3. Case 29. Pineocytoma/pineoblastoma. A: Intraoperative photograph showing endoscopic view of entry into aqueduct with posterior commissure $(\mathrm{P})$ compressed by tumor tissue $(\mathrm{T})$. B: Endoscopic view of stent $(\mathrm{S})$ placed within aqueduct. C: Sagittal contrast-enhanced $\mathrm{T}_{1}$-weighted MR image showing a tumor of the pineal region with aqueduct compression. D: Postoperative sagittal $\mathrm{T}_{2}$-weighted MR image showing stent in place.

The symptoms of increased ICP resolved in all of the 22 patients with obstruction of the CSF pathways. In the patient in Case 29, despite the absence of ventricular enlargement on the MR image, there was no doubt that the symptoms were related to intermittent obstruction of the aqueduct by the tumor, with resulting intermittent increases in ICP. After stent implantation the symptoms resolved immediately. One patient (Case 25) suffered from headaches that were not characteristic for intracranial hypertension and had moderately enlarged ventricles that were probably related to brain atrophy caused by previous radiation therapy rather than to CSF pathway obstruction.

The mean duration of the 28 strictly endoscopic procedures was only 85 minutes, ranging from 35 to 170 minutes. No endoscopic procedure had to be abandoned because of technical problems, significant bleeding, or poor orientation of the endoscope. In the two subependymomas that were larger than $2 \mathrm{~cm}$ in diameter (Cases 1 and 20), piecemeal endoscopic resection was ineffective because of the firm tissue consistency and tumor size. Therefore the endoscopic procedure was abandoned and the tumors were microsurgically removed. The duration of these combined operations was 135 and 210 minutes, respectively.

There were no endoscopy-related deaths. Two patients (Cases 3 and 18) died of tumor progression. The girl with the giant pituitary adenoma (Case 12) died of diencephalic dysfunction after microsurgical tumor extirpation. In two patients (Cases 16 and 24), significant bleeding occurred, obscuring a clear view through the bloody CSF. This bleeding could be controlled endoscopically; the CSF was aspirated and hemostasis could then be achieved in a dry field. The postoperative course was uneventful in both cases. We observed one case of meningitis after third ventriculostomy and tumor biopsy (Case 27), which resolved after treatment with antibiotic drugs. Because an external ventricular drain had been inserted in this patient 2 days before the endoscopic procedure, the meningitis was attributed to the drain rather than to the endoscope. In one patient (Case 20), transient mutism was observed. Memory loss attributed to forniceal injury occurred in two patients (Cases 15 and 20) and in Case 15 it is permanent. We noted transient trochlear palsy after a biopsy sample of an aqueductal tumor was obtained (Case 25) and transient confusion after a biopsy specimen of a suprasellar germinoma was obtained (Case 28). 
Endoscopic treatment of intraventricular tumors is rarely reported in the literature.[1,2,8,10,14,17,21,24,25,28,29,33,46,49] Most authors used endoscopy to obtain tumor biopsy specimen. Details concerning endoscopic technique, complications, and outcome were rarely given in the published reports. The intraventricular lesions most often treated endoscopically are colloid cysts of the third ventricle. As early as 1963, Guiot, et al.,[30] reported the use of ventriculoscopy in a patient with a colloid cyst. In the following years several other authors treated colloid cysts successfully by using endoscopic techniques.[14,15,18,38,53,59,60]

The transcallosal-transventricular,[4,32] transcortical-transventricular,[4,39,45,48] transcallosal-interforniceal,[6] transcortical-transventricular stereotactic[3,12] approaches, and stereotactically guided aspiration[11,19,31,35,47] have been recommended for the treatment of colloid cysts. Shunt placement should not be considered as a treatment option because of its high rate of complications.[13] Although a complete cyst removal is the rule with microsurgery,[22] potential risks are well known. Complications associated with the transcallosal approach include venous infarction, thrombosis of the sagittal sinus, disconnection syndromes, forniceal injury, and infarcts to the thalamus and basal ganglia.[40] The transcortical approach is also reported to be associated with a higher rate of seizures.[39,45] Because of its simplicity and low risk, stereotactically guided aspiration of colloid cysts based on CT scans has been advocated.[11,19] However, in hyperdense cysts (an indication of solid content), stereotactically guided aspiration often failed,[35] necessitating an endoscopic or microsurgical procedure.[36] Moreover, stereotactically guided aspiration has the potential to injure the fornix and cause bleeding from ependymal veins.[38] A recent review of 10 stereotactically guided aspirations, including seven performed with endoscopic guidance, revealed a $40 \%$ risk of transient memory deficit (10\% permanent).[44] Most importantly, a recurrence rate of up to 80\% following aspiration of colloid cysts has been reported after long-term follow-up review.[44] Recurrences were detected even 8 to 15 years posttreatment.[43] This underlines the fact that simple aspiration is not sufficient. The key seems to be a wide opening of the cyst with complete or nearly complete resection of the capsule. Because sudden death caused by colloid cysts has been reported, $[3,55,56]$ even asymptomatic cysts that cause minimal signs of CSF flow obstruction should be surgically treated.

In our series of seven colloid cysts, each lesion contained at least partially solid components. Hence, simple stereotactically guided aspiration would probably not result in a complete evacuation of the cyst. Using endoscopic techniques, a total evacuation and at least near-total resection of the membrane were achieved in all cases, and no additional procedures were necessary. In two patients (Cases 17 and 30), an external ventricular drain was inserted to prevent aseptic meningitis. However, even in the patients in whom no external drain was placed, no aseptic meningitis was observed. The forced irrigation probably eliminated the irritating material. Two episodes of venous bleeding occurred, one minor (Case 30) and one major (Case 24), but were controlled endoscopically. The minor bleeding stopped spontaneously after some minutes of irrigation, and in the patient with major bleeding hemostasis was achieved by means of bipolar coagulation in a dry field after aspiration of CSF. All patients improved and had been doing well as of the last follow-up examination. No cyst recurrence has been demonstrated as yet on MR images obtained in these patients. However, the question remains whether small remnants of the membrane that are left in place will later cause cyst recurrence. Only long-term evaluations performed more than 10 to 15 years after surgery can answer this question.

The aim of surgery for colloid cysts is restoration of the foramina of Monro with resolution of hydrocephalus and prevention of recurrent blockade of the foramina. This can be achieved with microsurgical and endoscopic techniques. Although the morbidity and mortality rates associated with microsurgical removal of colloid cysts are low today in experienced hands, the endoscopic minimally invasive burr hole approach is less traumatic to the brain and just as effective. Recently, Mathiesen, et al.,[43] reported on a series of 24 microsurgical colloid cyst removals ( 22 transcallosal and two transcortical) performed by experienced neurosurgeons. Despite these physicians' skill, transient memory deficit from forniceal traction was noted in $26 \%$ of cases. Two colloid cysts treated by less experienced surgeons even resulted in death or permanent memory loss. The authors stressed that piecemeal removal, as they do it, by means of endoscopic techniques, rather than in toto removal, is the key to avoiding forniceal injury and subsequent memory impairment. The endoscopic approach combines the minimal invasiveness of stereotactically guided aspiration with the effectiveness of microsurgery. Therefore, we consider the endoscopic removal of colloid cysts to be the therapy of choice. However, the operating microscope should be kept ready to aid immediate microsurgical intervention in case of complications or ineffectiveness of the endoscopic procedure.

A major problem in the endoscopic management of tumors is hemostasis. Small hemorrhages occur during nearly all tumor resections or biopsies, and even a small amount of bleeding may completely obscure the operative view. Therefore, all procedures must be performed in concert with continuous irrigation. Fortunately, most bleeding stops spontaneously after a few minutes. In significant bleeds, hemostasis can be achieved by means of bipolar diathermy. Two of our patients experienced major bleeds, but no procedure had to be abandoned for this reason. In these cases, we aspirated the CSF to make hemostasis easier in a dry field. There were no neurological sequelae resulting from intraoperative hemorrhage in any case.

The use of endoscopically guided biopsy techniques provides some advantages compared with stereotactically guided biopsy 
based on MR or CT imaging. First, direct visualization of the lesion is feasible. In this way, changes in coordinates, for example after cyst aspiration, can be recognized. Second, the procedure can be monitored: hemorrhages can be detected early and hemostasis achieved aided by visual control. We consider the endoscopic approach to be superior to the stereotactic approach to obtaining a biopsy specimen for intraventricular lesions in the pineal region. Despite recent reports on large series of stereotactically obtained biopsy samples of pineal lesions[37,54] in which this technique is described as safe and reliable, we are concerned about the "blind" sampling of tissue specimens in this area. We prefer to perform neuroendoscopic exploration and to obtain biopsy samples under direct view of the field. Any CSF pathway obstruction that accompanies these lesions can easily be resolved by stenting of the aqueduct or by third ventriculostomy using the same approach. Thus, endoscopy offers histological verification and permanent resolution of increased ICP. After attaining an accurate histological diagnosis the choice is made between microsurgical operation, radiation therapy, chemotherapy, and/or radiosurgery.

A limiting factor in endoscopic tumor resection is the size of the lesion. However, it is difficult to determine an exact size limit for endoscopic tumor removal. In general, a solid tumor should not exceed $2 \mathrm{~cm}$ in diameter; otherwise its removal takes too long. Another important point is the consistency of the tumor: a soft tumor is more easily resected than a firm one. Most neuroendoscopes that are currently available have a narrow working channel of at best $2.4 \mathrm{~mm}$. It is clear that removal even of small solid tumors is a prolonged procedure with these scopes. The benefit of the minimally invasive technique featuring less brain retraction and a small burr hole approach is then outweighed by the duration of the operation. Our operating endoscope has no separate working channel. The whole inner diameter $(>6 \mathrm{~mm})$ of the operative sheath through which the endoscope is introduced can be used for the removal of large tumor pieces. Some authors advocate the introduction of a second working porta enabling the use of larger instruments and, in this way, speeding up tumor removal.[14,34] We do not recommend the routine use of two portals because it makes the neuroendoscopic approach as invasive as standard microsurgical procedures. It might be useful to insert an ultrasonic aspirator simultaneously via a second port when removing selected solid tumors. However, in no case in this series, in which we used our system with one large working space, was another port necessary. A new operating scope with a 7-mm working space is now being developed.

In patients with accompanying hydrocephalus, it is usually sufficiently accurate to make the burr hole according to the best trajectory obtained from MR images. However, if the ventricles are small or if the lesions are located in the posterior part of the third ventricle, precise guidance is helpful to follow the ideal access route to the target, thus avoiding unnecessary brain trauma. Frame stereotaxy,[5,23,29,50-52,60] ultrasound-guided stereotaxy,[7] and recently, frameless computer-based stereotaxy[20,41,42] have been used in combination with neuroendoscopy to facilitate high accuracy in determining the surgical approach. In four patients (Cases 26 and 28-30), we used infrared-based computerized neuronavigation adapted to neuroendoscopic demands, which we developed in cooperation with the Carl Zeiss company. This device guided us precisely in a straight line to the target. In comparison to frame stereotaxy as the gold standard of accuracy, computerized frameless navigation enables free-hand positioning of the endoscope with real-time control of the position of the endoscope tip and of the approach trajectory. Accuracy was between 2 and $3 \mathrm{~mm}$, which proved to be sufficient for endoscopic purposes. After approaching the target using neuronavigational guidance, minor position corrections can be made by means of direct vision.

In our series, endoscopic management of intraventricular tumors proved to be minimally invasive and effective. Microsurgical dissection of the brain was avoided in all but two patients in whom firm subependymomas larger than $2 \mathrm{~cm}$ in diameter required microsurgical removal because the initial endoscopic tumor resection was ineffective. The symptoms related to increased ICP have resolved in all patients, and all implanted stents have remained in place. All third ventriculostomies have been patent; the need for a shunt was completely eliminated in this series. A histological diagnosis was made in all but one thalamic tumor and additional therapy, such as microsurgery, chemotherapy, or radiation therapy, could then be initiated. Because the patient with the thalamic tumor is free of symptoms and the radiological appearance of this tumor, which is located underneath the ventricular surface, is typical for a low-grade glioma, no additional attempt has been made to arrive at a final histological diagnosis. The three deaths were not related to endoscopy but were caused by tumor progression and diencephalic dysfunction after microsurgery. Most of the morbidity observed was transient. There was one patient who suffered permanent memory loss caused by forniceal injury after a transcallosal approach. Because this approach is more complex (a small craniotomy and microsurgical dissection to expose the corpus callosum are required) and initial orientation is more difficult, we subsequently abandoned this route of access for endoscopic procedures. The transcortical burr hole approach is easy, fast, and safe (it features well-known landmarks). After treating more than 160 cases, we have seen no seizures caused by transcortical insertion of an endoscope.

\section{CONCLUSIONS}

The introduction of the operating microscope in the 1960s facilitated challenging procedures made through small openings into the depth of the brain. With application of neuroendoscopic techniques, invasiveness can now be further reduced, with comparable or even better results. Selected intraventricular tumors may be removed completely via an endoscopic approach, 
avoiding craniotomies and brain retraction. The access to the lesion is rapid and straightforward. The duration of the endoscopic procedures is usually shorter than expected with microsurgery, and obstructed CSF pathways causing hydrocephalus may be restored to patency via the same approach.

Endoscopic techniques must be compared with microsurgical approaches according to the results obtained.[9] However, the neuroendoscopic management of intraventricular tumors is still at its very beginning, and there is a steep learning curve for endoscopic procedures. Long-term follow up and larger series are necessary to demonstrate which approach is best for which lesion. Nevertheless, endoscopic techniques should be seriously considered in the treatment of selected intraventricular lesions.

\section{Acknowledgments}

We thank Dr. S. Segal (St. Louis, MO) for his assistance in preparing the manuscript.

\section{References}

1. Abbott R: Endoscopic resection of intraventricular tumors. Childs Nerv Syst 11:539, 1995 (Abstract)

2. Abdullah J, Caemaert J: Endoscopic management of craniopharyngiomas: a review of 3 cases. Minim Invasive Neurosurg 38:79-84, 1995

3. Abernathey CD, Davis DH, Kelly PJ: Treatment of colloid cysts of the third ventricle by stereotaxic microsurgical laser craniotomy. J Neurosurg 70:525-529, 1989

4. Antunes JL, Louis KM, Ganti SR: Colloid cysts of the third ventricle. Neurosurgery 7:450-455, 1980

5. Apuzzo MLJ, Chandrasoma PT, Zelman V, et al: Computed tomographic guidance stereotaxis in the management of lesions of the third ventricular region. Neurosurgery 15:502-508, 1984

6. Apuzzo MLJ, Chikovani OK, Gott PS, et al: Transcallosal, interfornicial approaches for lesions affecting the third ventricle: surgical considerations and consequences. Neurosurgery 10:547-554, 1982

7. Auer LM: Ultrasound stereotaxic endoscopy in neurosurgery. Acta Neurochir Suppl 54:34-41, 1992

8. Auer LM, Holzer P, Ascher PW, et al: Endoscopic neurosurgery. Acta Neurochir 90:1-14, 1988

9. Bauer BL, Hellwig D: Current endoneurosurgery. Adv Neurosurg 22:113-120, 1994

10. Bauer BL, Hellwig D: Minimally invasive endoscopic neurosurgery--a survey. Acta Neurochir Suppl 61:1-12, 1994

11. Bosch DA, Rähn T, Backlund EO: Treatment of colloid cysts of the third ventricle by stereotactic aspiration. Surg Neurol 9:15-18, 1978

12. Cabbell KL, Ross DA: Stereotactic microsurgical craniotomy for the treatment of third ventricular colloid cysts.

Neurosurgery 38:301-307, 1996

13. Camacho A, Abernathey CD, Kelly PJ, et al: Colloid cysts: experience with the management of 84 cases since the introduction of computed tomography. Neurosurgery 24:693-700, 1989

14. Cohen AR: Endoscopic ventricular surgery. Pediatr Neurosurg 19:127-134, 1993

15. Cohen AR: Ventriculoscopic surgery. Clin Neurosurg 41:546-562, 1994

16. Collmann H, Kazner E, Sprung C: F. Lateral and third ventricle. Supratentorial intraventricular tumors in childhood. Acta Neurochir Suppl 35:75-79, 1985

17. Decq P, Yepes C, Anno Y, et al: L'Endoscopie neurochirurgicale. Indications diagnostiques et thérapeutiques.

Neurochirurgie 40:313-321, 1994

18. Deinsberger W, Böker DK, Samii M: Flexible endoscopes in treatment of colloid cysts of the third ventricle. Minim Invas Neurosurg 37:12-16, 1994

19. Donauer E, Moringlane JR, Ostertag CB: Colloid cysts of the third ventricle. Open operative approach or stereotactic aspiration? Acta Neurochir 83:24-30, 1986

20. Drake JM, Prudencio J, Holowka S, et al: Frameless stereotaxy in children. Pediatr Neurosurg 20:152-159, 1994 
21. Eiras Ajuria J, Alberdi Vinas J: Traitement endoscopique des lésions intracrâniennes. A propos de 8 cas. Neurochirurgie 37:278-283, 1991

22. Findlay JM: Colloid cyst removal. J Neurosurg 82:703, 1995 (Letter)

23. Frank E: An adjustable ventriculoscope guide for use with stereotactic frames. Neurosurgery 29:789-790, 1991

24. Fukushima T: Endoscopic biopsy of intraventricular tumors with the use of a ventriculofiberscope. Neurosurgery

2:110-113, 1978

25. Fukushima T, Ishijima B, Hirakawa K, et al: Ventriculofiberscope: a new technique for endoscopic diagnosis and operation. Technical note. J Neurosurg 38:251-256, 1973

26. Gaab MR: A universal neuroendoscope: development, clinical experience, and perspectives. Childs Nerv Syst 10:481, 1994 (Abstract)

27. Gaab MR, Schroeder HWS: Endoscopic approach to lesions of the foramen of Monro. Zentralbl Neurochir Suppl 56:42, 1995 (Abstract)

28. Griffith HB: Endoneurosurgery: endoscopic intracranial surgery. Adv Tech Stand Neurosurg 14:2-24, 1986

29. Grunert P, Perneczky A, Resch K: Endoscopic procedures through the foramen interventriculare of Monro under stereotactical conditions. Minim Invasive Neurosurg 37:2-8, 1994

30. Guiot G, Rougerie J, Fourestier M, et al: [Intracranial endoscopic explorations.] Presse Med 71:1225-1228, 1963 (Fr)

31. Hall WA, Lunsford LD: Changing concepts in the treatment of colloid cysts. An 11-year experience in the CT era. J Neurosurg 66:186-191, 1987

32. Hernesniemi J, Leivo S: Management outcome in third ventricular collloid cysts in a defined population: a series of 40 patients treated mainly by transcallosal microsurgery. Surg Neurol 45:2-14, 1996

33. Hor F, Desgeorges M, Rosseau GL: Tumour resection by stereotactic laser endoscopy. Acta Neurochir Suppl 54:77-82, 1992

34. Jallo GI, Morota N, Abbott R: Introduction of a second working portal for neuroendoscopy. A technical note. Pediatr Neurosurg 24:56-60, 1996

35. Kondziolka D, Lunsford LD: Stereotactic management of colloid cysts: factors predicting success. J Neurosurg 75:45-51, 1991

36. Kondziolka D, Lunsford LD: Stereotactic techniques for colloid cysts: roles of aspiration, endoscopy, and microsurgery. Acta Neurochir Suppl 61:76-78, 1994

37. Kreth FW, Schätz CR, Pagenstecher A, et al: Stereotactic management of lesions of the pineal region. Neurosurgery 39:280-291, 1996

38. Lewis AI, Crone KR, Taha J, et al: Surgical resection of third ventricle colloid cysts. Preliminary results comparing transcallosal microsurgery with endoscopy. J Neurosurg 81:174-178, 1994

39. Little JR, MacCarty CS: Colloid cysts of the third ventricle. J Neurosurg 40:230-235, 1974

40. Manwaring KH: Intracranial neuroendoscopy: review of recent papers. Crit Rev Neurosurg 5:63-72, 1995

41. Manwaring KH, Hamilton AJ: Neurosurgical endoscopy, in Tindall GT, Cooper PR, Barrow DL (eds): The Practice of Neurosurgery. Baltimore: Williams \& Wilkins, 1996, pp 233-242

42. Manwaring KH, Manwaring ML, Moss SD: Magnetic field guided endoscopic dissection through a burr hole may avoid more invasive craniotomies. A preliminary report. Acta Neurochir Suppl 61:34-39, 1994

43. Mathiesen T, Grane P, Lindgren L, et al: Third ventricle colloid cysts: a consecutive 12-year series. J Neurosurg 86:5-12, 1997

44. Mathiesen T, Grane P, Lindquist C, et al: High recurrence rate following aspiration of colloid cysts in the third ventricle. J 
Neurosurg 78:748-752, 1993

45. McKissock W: The surgical treatment of colloid cyst of the third ventricle. A report based upon twenty-one personal cases. Brain 74:1-9, 1951

46. Merienne L, Leriche B, Roux FX, et al: Utilisation du laser Nd-YAG en endoscopie intracranienne. Expérience préliminaire en stéréotaxie. Neurochirurgie 38:245-247, 1992

47. Mohadjer M, Teshmar E, Mundinger F: CT-stereotaxic drainage of colloid cysts in the foramen of Monro and the third ventricle. J Neurosurg 67:220-223, 1987

48. Nitta M, Symon L: Colloid cysts of the third ventricle. A review of 36 cases. Acta Neurochir 76:99-104, 1985

49. Oka K, Yamamoto M, Nagasaka S, et al: Endoneurosurgical treatment for hydrocephalus caused by intraventricular tumors. Childs Nerv Syst 10:162-166, 1994

50. Otsuki T, Jokura H, Nakasato N, et al: Stereotactic endoscopic resection of angiographically occult vascular malformations. Acta Neurochir Suppl 61:98-101, 1994

51. Otsuki T, Jokura H, Yoshimoto T: Stereotactic guiding tube for open-system endoscopy: a new approach for the stereotactic endoscopic resection of intra-axial brain tumors. Neurosurgery 27:326-330, 1990

52. Otsuki T, Yoshimoto T, Jokura H, et al: Stereotactic laser surgery for deep-seated brain tumors by open-system endoscopy. Stereotact Funct Neurosurg 54/55:404-408, 1990

53. Powell MP, Torrens MJ, Thomson JLG, et al: Isodense colloid cysts of the third ventricle: a diagnostic and therapeutic problem resolved by ventriculoscopy. Neurosurgery 13:234-237, 1983

54. Regis J, Bouillot P, Rouby-Volot F, et al: Pineal region tumors and the role of stereotactic biopsy: review of the mortality, morbidity, and diagnostic rates in 370 cases. Neurosurgery 39:907-914, 1996

55. Ryder JW, Kleinschmidt-DeMasters BK, Keller TS: Sudden deterioration and death in patients with benign tumors of the third ventricle area. J Neurosurg 64:216-223, 1986

56. Saulsbury FT, Sullivan JS, Schmitt EJ: Sudden death due to colloid cyst of the third ventricle. Clin Pediatr 20:218-219, 1981

57. Schroeder HWS, Gaab MR: Endoscopic neurosurgery. Crit Rev Neurosurg 6:241-247, 1996

58. Schroeder HWS, Gaab MR: Endoscopic treatment of colloid cysts. Minim Invas Ther 5 (Suppl 1):99, 1996 (Abstract)

59. Warnke PC, Hans FJ, Jaiswa V, et al: Stereotactic-endoscopic therapy of colloid cysts. Adv Tech Stand Neurosurg

22:135-139, 1994

60. Zamorano L, Chavantes C, Moure F: Endoscopic stereotactic interventions in the treatment of brain lesions. Acta Neurochir Suppl 61:92-97, 1994

Manuscript received November 2, 1998.

Accepted in final form March 4, 1999.

Address reprint requests to: Michael R. Gaab, M.D., Ph.D., Department of Neurosurgery, Ernst Moritz Arndt University, Sauerbruchstrasse, D-17487, Greifswald, Germany. 